\title{
REPRESENTASI MITOS KECANTIKAN DALAM KOLOM FEMALE
}

\author{
Yelly Elanda \\ Program Studi Sosiologi, Fakultas Ilmu Sosial dan Ilmu Politik \\ Universitas Wijaya Kusuma Surabaya \\ Email:yelly.elanda@gmail.com
}

\begin{abstract}
Abstrak
Media online banyak diminati oleh masyarakat karena kecepatan dan kemudahan dalam memperoleh informasi. Media online Kompas.com misalnya memiliki kolom female dimana kolom tersebut banyak membahas masalah kecantikan. Melalui berita kecantikan, kolom female mengkonstruksi mitos kecantikan. Kolom tersebut juga mengkaitkan antara tubuh dan lingkungan sosialnya yakni dalam hal percintaan, pola asuh anak dan dalam hal karier untuk membentuk citra tubuh. Tulisan ini adalah mengetahui dan mengidentifikasi representasi mitos kecantikan dalam kolom female. Mengidentifikasi dan membongkar ideologi mitos kecantikan yang diwacanakan oleh kolom female melalui teks berita. Tulisan ini merupakan hasil penelitian dengan menggunakan analisis wacana kritis dengan model pendekatan perubahan sosial yang diutarakan oleh Norman Fairclough. Penelitian ini dilakukan hanya pada level mikro (level teks) yang terbit pada kolom female media online Kompas.com dari bulan oktober hingga desember 2014 dan januari hingga maret 2015 dengan 128 pemberitaan. Hasil penelitian ini adalah kolom female dalam media online Kompas.com yang senyatanya merupakan ruang untuk mengakomodir kepentingan perempuan justru membentuk wacana mitos kecantikan dengan menjadikan perempuan dan laki-laki sebagai objek konsumtif dan objek kenikmatan. Iron maiden digambarkan dengan sosok variatif dengan hanya mengandalkan kecantikan fisik, tanpa melihat inner beauty. Meskipun menghadirkan variasi mitos kecantikan, namun kolom female masih merujuk pada ras kaukasoid. Sosok yang berbeda dari iron maiden mendapatkan streotipe tertentu. Tulisan di kolom female hanya muatan dari kepentingan kapitalis dalam mengkonstruksi kecantikan secara subjektif. Berita dari kolom female masih memperlihatkan betapa kuatnya ideologi kapitalis dan budaya patriarkhi.
\end{abstract}

Kata Kunci : Ideologi, Media, Mitos Kecantikan, Representasi, Wacana

\begin{abstract}
Media online much in demand by the community because of the speed and ease in obtaining information. Media online Kompas.com for example has a female column where the column discussed many beauty issues. Female columns also relate between body and social environment in terms of romance, parenting and in terms for construct body image. This article is information and presentation of mythical representation in online media Kompas.com. Identify and dismantle the ideology of beauty myths discourse by the female column through the news text. This article is the result of research by uses critical discourse analysis with social change approach model expressed by Norman Fairclough. This research was conducted only at the micro level (text level) published in the female online media column Kompas.com from October to December 2014 and January to 2015 with 128 news. The result of the research is female column in Kompas.com online media which is actually a space to accommodate women's
\end{abstract}


interests precisely forming the discourse of beauty myth by making women and man as consumptive object and enjoyment object. Iron maiden is depicted with a varied figure with only rely on physical beauty, without seeing inner beauty. Although presenting a variety of beauty myths, but online media Kompas.com still refers to race kaukasoid. Different figures of iron maiden get certain streotype. Writing in the female column is only the content of the capitalist interest in constructing the subjective beauty. News from the female column still shows how strong the capitalist ideology and patriarchal culture.

\section{Keywords : Ideology, Media, Beauty Myth, Representation, Discourse}

\section{PENDAHULUAN}

Tubuh bukan hanya sekedar susunan tulang dan daging yang bisa dilihat secara biologis namun tubuh juga memiliki makna sosiologis dengan berbagai simbol atribut yang melekat padanya. Oleh karena itu, tubuh tidak lagi dimiliki secara privat tapi sebagai milik publik dimana tubuh menjadi arena penilaian dan konstruksi. Tubuh pun tidak luput dari serangan wacana dengan memperhatikan konteks ruang dan waktu. Wacana tubuh tentunya tidak terlepas dari adanya kekuasaan dan pengetahuan. Kekuasaan akan melegitimasi pengetahuan dan pengetahuan akan digunakan untuk menjalankan suatu kuasa, keduanya saling melengkapi. Tubuh dikontrol, didisiplinkan dan diawasi melalui wacana. ${ }^{1}$

Wacana erat kaitannya dengan ideologi dan kekuasaan. Ideologi dan kekuasaan itu tidak terlepas dari tangan-tangan kapitalis. Setiap ideologi saling memperebutkan, mempertahankan dan memperluas kekuasaannya. Media memiliki peran penting untuk menanamkan ideologi terutama yang akan dibahas melalui berita. Wartawan dan editor memiliki kendali untuk memilih, mengkonsep berita sesuai dengan ide kreatif mereka. Ada peran aktif dari wartawan dengan mengkonsep realitas yang dia temukan dengan framingnya baru kemudian disajikan dalam bentuk berita dan berita ini dapat secara aktif mengkonstruksi pembaca sesuai dengan apa yang diinginkan oleh wartawan atau pembuat berita. Dalam berita wartawan secara tidak langsung telah menyampaikan bentuk ideologinya. Pemberitaan yang dilakukan oleh wartawan dalam mengkonstruksi tubuh tidak terlepas dari kepentingan ekonomi, sosial, politik dan budaya. ${ }^{2}$

Kajian teks yang menghubungkan antara ideologi dan bahasa ini menjadi menarik, sehingga banyak yang melakukan penelitian dengan menggunakan analisis wacana kritis untuk mengetahui representasi suatu kelompok dan untuk mencari tahu ideologi apa yang terdapat dalam suatu teks. Sebagaimana penelitian yang telah dilakukan pada beberapa surat kabar atau majalah. Empat majalah Kartini edisi bulan juli 2009 dan empat majalah Femina edisi bulan desember 2009 yang segmentasi pasarnya perempuan kelas menengah perkotaan juga tidak terlepas dari kelima citra yakni: citra pigura, pilar, peraduan, pinggan dan pergaulan melalui cover story. ${ }^{3}$ Kemudian penelitian selanjutnya juga dilakukan pada majalah Femina edisi 2011. Hasilnya adalah tubuh perempuan dikonstruksi dan direkayasa

\footnotetext{
${ }^{1}$ Synnott, Anthony. 2007. Tubuh Sosial. Yogyakarta: Jalasutra. Hlm. 41

${ }^{2}$ Fairclough, Norman. 1995. Critical Discourse Analysis:The Critical Study of Language. Singapore: Longman Singapore Publishers (Pte) Ltd. Hlm. 25

${ }^{3}$ Siregar, Aprilandini Yuanita. 2011. Pencitraan Perempuan di Majalah: Konstruksi Identitas Perempuan Kelas Menengah di Perkotaan. Jurnal Komunitas. Volume 5 Nomor 1. 1-24
} 
secara sosial sesuai dengan mitos yang ingin dibangun oleh media yang bersangkutan. Tubuh perempuan sengaja dijadikan sebagai objek dan sasaran dari kegiatan konsumtif. ${ }^{4}$ Penelitian selanjutnya pada media cetak lokal Harian Haluan Padang. Ada dua pencitraan wanita Minangkabau yang menjadi peserta kontak jodoh yakni: pertama, pencitraan yang dilakukan oleh pengasuh rubrik kontak jodoh dengan berpatokan pada data diri dan melakukan penafsiran foto peserta. Kedua, pencitraan yang dikonstruksi oleh media melalui judul rubrik.Media biasanya mempertegas salah satu simbol yang menjadi keunikan sebuah teks dengan pertimbangan aspek daya tarik judul dan nilai jualnya. ${ }^{5}$

Ketiga penelitian tersebut masih menjadikan media cetak sebagai objek kajian. Perkembangan teknologi informasi hari ini, media online memiliki pangsa pasar yang cukup luas dan banyak diminati. Generasi milenial yang mengandalkan kecepatan iniformasi, lebih memilih menjadi penikmat media online. Salah satu media online yang memiliki kredibilitas tinggi dan banyak pengunjungnya adalah media online Kompas.com. Hal ini dibuktikan dengan adanya jumlah pengunjung aktif Kompas.com di awal tahun 2008 yang mencapai 20 juta pembaca aktif per bulan, dan total 40 juta page views/impression per bulan. Saat ini, Kompas.com telah mencapai 120 juta page view perbulan. ${ }^{6}$ Dengan jumlah viewers yang relatif meningkat maka banyak iklan yang masuk dalam media online Kompas.com untuk memasarkan produknya. Situs Kompas.com memberikan banyak varian berita atau informasi diantaranya terdapat kolom khusus mengenai wanita yaitu kolom female. Kolom female banyak menyediakan informasi yang berkaitan dengan permasalahan yang biasanya dihadapi oleh wanita. Ada 11 sub kolom yang ada dalam kolom female diantaranya home, ibu dan anak, etalase, cantik dan gaya, relationship, bugar dan sehat, beranda, dapur, dan konsultasi. Kesebelas kolom tersebut berisi segala hal yang berkaitan dengan kegiatan wanita baik dalam domestik (macak, manak, masak) dan juga dalam kegiatan karier (profesi atau pekerjaan). Kolom female memiliki wewenang untuk memilih dan bahkan mengkonsep berita yang akan dimuat. Kolom female memiliki tujuan untuk mengkonstruksi citra tubuh pembaca. Kolom female memiliki perbedaan dalam mengkonsep tubuh sebagaimana kolom health memberikan informasi. Kolom female seolah memberikan informasi hanya terhadap perempuan dengan label femininnya, namun ternyata mitos kecantikan tengah dilancarkan pula pada pria.

Media merupakan arena pertarungan wacana dimana wacana dominan akan dipercaya sebagai suatu kebenaran. Perkembangan media memiliki pengaruh yang cukup signifikan dalam membentuk pola pikir, perilaku dan budaya para pembacanya. Melalui media tubuh dibentuk dan disiplinkan dengan menjadi sosok iron maiden. Iron maiden adalah sosok tubuh ideal yang digambarkan secara sempurna oleh "penguasa" dengan menggunakan mitos kecantikan. ${ }^{7}$ Mitos kecantikan tidak bisa dipisahkan dari konstruksi yang begitu gencar dilakukan oleh media. Oleh karena itu, kajian mengenai representasi mitos kecantikan ini menjadi menarik untuk ditelisik lebih jauh sekaligus dengan menguak ideologi yang berada di belakang mitos

\footnotetext{
${ }^{4}$ Marlianti, Nelly dan Suryani, Ade. 2012. Representasi Tubuh Perempuan dalam Rubrik Kecantikan di Majalah Femina Edisi Mei 2011. Jurnal Komunikasi Volume 9 Nomor 2. 67-73

${ }^{5}$ Erianjoni. 2009. Konstruksi Media terhadap Pencitraan Wanita: Studi Semiotik Pencitraan Wanita Minangkabau dalam Rubrik Kontak Jodoh di Media Lokal Harian Haluan Padang. Jurnal Demokerasi Volume VIII No. 2. 107-129

${ }^{6}$ (http://inside.kompas.com/about-us) diakses tanggal 10 oktober 2015

${ }^{7}$ Wolf, Naomi. 2004. Mitos Kecantikan. Yogyakarta: Niagara
} 
kecantikan yang direpresentasikan oleh media. Terlebih kolom female tidak hanya membentuk mitos kecantikan bagi perempuan saja tapi juga bagi laki-laki.

\section{METODE PENELITIAN}

Penelitian ini menggunakan metode analisis wacana kritis yang biasanya digunakan untuk membedah suatu teks. Analisis wacana kritis ini dikenal dengan istilah CDA (Critical Discourse Analysis) yang melihat berita atau di dalam teks terdapat kekuasaaan yang dimiliki oleh kaum dominan untuk melanggengkan status quonya melalui pengetahuan yang diwacanakan. Media merupakan aspek terpenting dalam hal ini untuk menyebarkan ideologi kelompok dominan dan kelompok dominan juga sangat mudah untuk mendapatkan akses pada media. Oleh karena itu pandangan kritis menyatakan bahwa relasi kuasa yang terjalin dalam suatu media banyak dipengaruhi konteks ekonomi, sosial, politik dan budaya dari suatu masyarakat. Kelompok dominan akan memanfaatkan kondisi ekonomi, sosial, politik dan budaya untuk menyebarkan ideologinya melalui media dan tentunya media tidaklah netral dalam mengemas suatu berita. ${ }^{8}$

Analisis wacana kritis yang digunakan dalam penelitian ini adalah pendekatan perubahan social dengan model Norman Fairclough. Fairclough banyak dipengaruhi oleh pemikiran Foucault tentang pembentukan subjek melalui wacana, pengetahuan dan kuasa, Julia Kristeva dan Bakhtin tentang intertekstualitas. Fairclough menggunakan pendekatan perubahan sosial dimana dalam teks ini menghubungkan teks yang mikro dengan konteks masyarakat yang makro melalui perantara meso. Norman Fairclough membangun suatu model yang mengintegrasikan secara bersama-sama analisis wacana yang didasarkan pada linguistik dan pemikiran sosial dan politik, dan secara umum diintegrasikan pada perubahan sosial. Fairclough membagi analisa wacana menjadi tiga dimensi: teks, discourse practice, dan sociocultural practice. ${ }^{9}$ Namun penelitian ini hanya berada pada level mikro atau teks saja yang mencakup representasi, relasi dan identitas.

Peneliti mengambil berita di media online Kompas.com khususnya di kolom female, kemudian peneliti mengetik keyword kecantikan dan memilih berita yang hanya muncul di kolom female dengan rentang waktu pemberitaan 1 Oktober hingga 31 Desember 2014 dan 1 Januari hingga 31 Maret 2015 karena ingin melihat perubahan mitos kecantikan yang ingin ditampilkan oleh kolom female di awal tahun 2015. Peneliti menentukan waktu 6 bulan untuk pengambilan teks berita yang diterbitkan oleh kolom female untuk membatasi ruang kajian peneliti. Penentuan waktu pada analisis wacana kritis menjadi sangat penting karena setiap waktu akan mengubah berita dan framing apa yang ingin ditampilkan dalam kolom female. Terdapat 128 berita yang diterbitkan oleh kolom female dalam rentang waktu 6 bulan tersebut.

\section{HASIL DAN PEMBAHASAN}

\section{Iron Maiden dalam Kolom Female}

Kapitalis menciptakan dan menyebarkan wacana kecantikan agar perempuan tidak pernah puas dengan tubuh yang dimilikinya, sehingga perempuan terus terjebak dalam pendisiplinan tubuh dengan melakukan ritual kecantikan. Dengan melakukan perawatan tubuh dari berbagai ritual kecantikan yang ditawarkan maka ini akan menguntungkan kapitalis yang bergerak dalam sektor kecantikan

\footnotetext{
${ }^{8}$ Eriyanto. 2005. Analisi Framing. Yogyakarta: LkiS. Hlm. 19

${ }^{9}$ Idem.hlm. 17
} 
dan tentunya juga kapitalis yang bergerak dalam media. Media yang bertugas untuk menyebarluaskan wacana kecantikan melalui berbagai tulisan pemberitaannya.

Kolom female secara keseluruhan menginginkan adanya seorang iron maiden. Sosok perempuan yang memiliki kecantikan ideal dimana kecantikannya seolah tidak pernah ada di dunia nyata melainkan ada di dalam mitos kecantikan. Mitos kecantikan itu sengaja dibuat sebagai halusinasi sosok perempuan yang ideal untuk menjadikan perempuan lain merasa gusar terhadap penampilannya. ${ }^{10}$ Mitos kecantikan itu sengaja dibuat oleh kaum kapitalis untuk membuat standarisasi kecantikan ideal untuk melanggengkan kekuasannya. Wacana mitos kecantikan ini merupakan elemen taktis yang berpotensi dalam kancah relasi kekuasaan. ${ }^{11}$

Penggunaan model untuk merepresentasikan iron maiden pada kolom female banyak menggunakan artis yang terkenal dimulai dari Amerika, Eropa, Asia yang termasuk di dalamnya juga dari Indonesia. Dalam kolom female ternyata penggunaan model tidak hanya terbatas pada perempuan, namun juga laki-laki. Kolom female memberikan inspirasi dan citra tubuh ideal untuk laki-laki dan perempuan. Jadi kolom female tidak hanya menstandarisasi citra tubuh dan kecantikan perempuan namun juga bagi laki-laki. Cowok metroseksual yang dikenal saat ini juga merupakan wacana yang turut disebarkan oleh kolom female. Tidak hanya perempuan yang sangat memperhatikan penampilan dan kecantikannya namun laki-laki juga dituntut untuk itu.

Seorang iron maiden yang ditawarkan oleh kolom female digambarkan sebagai sosok perempuan yang memiliki kecantikan natural. Bukan berarti kata natural itu bisa terlepas dari penggunaan kosmetik, namun justru sangat dianjurkan untuk menggunakan tata rias yang semakin tebal agar nampak natural. Bahkan direkomendasikan untuk mengubah bagian tubuh yang tidak proporsional dengan melakukan operasi plastik. Penggunaan tata rias juga disesuaikan dengan konteks acara dan image yang akan ditampilkan sehingga memaksa perempuan untuk berbelanja alat kosmetik lebih banyak.

Sosok iron maiden, baik laki-laki maupun perempuan harus berwajah bersih, bercahaya, putih merona, tanpa noda dan kerutan. Noda dianggap sebagai suatu keburukan, artinya orang yang memiliki wajah yang kurang bercahaya maka dinilai memiliki hati yang buruk. ${ }^{12}$ Bentuk bibir yang dimiliki oleh iron maiden adalah tebal dan seksi sehingga banyak yang melakukan operasi plastik dan terapi untuk memiliki bibir yang demikian. Bentuk hidung yang diidamkan pun harus mancung. Dapat dilihat dari warna kulit, bentuk bibir dan hidung bahwa mitos kecantikan mendiskriminasi perempuan dan laki-laki secara ras. Iron maiden yang ditampilkan lebih merujuk pada ras kaukasoid, berkulit putih, berhidung mancung.

Kolom female memang menggambarkan sosok iron maiden yang ideal dengan menggunakan beberapa model, mulai model Amerika, Eropa, Indonesia, Cina dan Korea. Dengan penggunaan model yang demikian maka kolom female ingin menampilkan beragam kecantikan. Namun ternyata dalam pemberitaannya, sosok yang tidak sesuai dengan penggambaran iron maiden versi kolom female diberikan label tertentu. Pelabelan seksi, unik, wajah oriental atau diidentikkan dengan hal-hal yang berbau pornografi. Dengan adanya streotipe yang demikian maka sebenarnya kolom female ingin memperbandingkan beragam model dari berbagai ras kemudian secara tersirat ingin mengatakan bahwa model dengan ras kaukasoidlah

\footnotetext{
${ }^{10}$ Idem hlm. 8

${ }^{11}$ Darma, Aliah Yoce.2009. Analisis Wacana Kritis. Bandung: Yrama Widya. Hlm. 83-84

12 Idem. Hlm. 149
} 
yang jadi pemenangnya atau memiliki kecantikan yang sempurna.

Selain iron maiden digambarkan orang yang sempurna secara fisik, kolom female juga membahas inner beauty yang dimiliki. Kolom female menilai bahwa kecantikan fisik akan berpengaruh pada kebaikan hati dengan menyumbangkan materi atau kekayaannya pada orang yang membutuhkan. Hal ini mengindikasikan bahwa kecantikan akan berpengaruh pada kekayaan yang dimilikinya karena kecantikan menyimbolkan statusnya. ${ }^{13}$ Dengan mewacanakan hal demikian kolom female mengukur jiwa sosial hanya berdasarkan materi yang dikeluarkan untuk membantu sesama, bukan dari seberapa tulus dan pengorbanan apa yang diberikan bagi orang yang ditolong. Kolom female tidak pernah memberitakan kebaikan seseorang yang memberikan tenaganya atau pikirannya terhadap seseorang, melainkan materi yang diberikan. Dapat dilihat di sini bahwa pemikiran kolom female menggambarkan suatu hubungan yang bersifat materi, kebaikan diukur oleh materi, bukan dari seberapa besar manfaat yang telah diberikan pada orang lain. Pemikiran seperti ini mencerminkan sikap kapitalis.

Kolom female mewacanakan hal yang demikian agar perempuan berlomba-lomba untuk tampil cantik dan menarik karena perempuan menjadi percaya bahwa dengan cantik dan menarik dirinya terlihat sebagai orang yang memiliki kekayaan dan memiliki kepribadian yang baik. Dengan berlombalomba menjadi cantik maka yang diuntungkan adalah para kapitalis kecantikan dan media karena mereka yang memperkuat wacana ini. Wacana yang dimainkan oleh kapitalis membuat keyakinan perempuan untuk terus dikatakan sempurna oleh orang lain melalui kecantikan yang dimiliki. Dari sini nampak betapa kuatnya pengaruh wacana pada kehidupan. Pengetahuan yang digunakan oleh kolom female adalah dengan membawa pada suatu nalar yang dapat dipercaya dengan membatasi ruang pembicaraan sesuai dengan framing yang digunakannya. ${ }^{14}$

\section{Mitos Kecantikan dan Kehidupan Penganutnya}

Kecantikan akan menunjukkan suatu citra diri sehingga hal ini banyak dimainkan oleh kapitalis dalam membuat suatu iklan kecantikan. Kapitalis menggunakan wacana untuk membentuk suatu kebenaran tentang image tersebut. Sebagaimana dikatakan oleh Foucault bahwa episteme menentukan bagaimana cara kita memandang suatu objek. Episteme mengendalikan dan mengontrol tindakan manusia melalui tiga macam pengecualian yakni tabu, kegilaan dan ketidakbenaran. ${ }^{15}$ Dalam pembentukan episteme ini tidak luput dari peran kapitalis untuk menyulap suatu realitas menjadi hiperealitas agar mampu dianggap sebagai suatu kebenaran. Jika wacana itu sudah menjadi wacana dominan maka budaya konsumtif itu akan tercipta dan tentunya ini sangat menguntungkan kapitalis. Wacana yang dibuat adalah dengan menghubungkan antara kecantikan dengan karier dan pasangan.

Kolom female menempatkan wajah dan tubuh sebagai indikator kecantikan, dan kecantikan akan berpengaruh terhadap profesi serta kekayaan seseorang. Melalui wajah kita bisa melihat ekspresi dan wajah juga menyimbolkan kebaikan seseorang. Memiliki wajah, warna kulit dan tubuh yang bagus seolah-olah akan berdampak pada masa depan karier seseorang. Kolom female mengkaitkan antara peran, kecantikan dan penampilan sebagai suatu gerakan feminisme yang akan menginspirasi berbagai kalangan perempuan. Padahal dengan adanya standarisasi kecantikan dan penampilan akan mendiskriminasi perempuan untuk tidak

\footnotetext{
${ }^{13}$ Idem. Hlm. 147

${ }^{14}$ Barker, Chris. Cultural Studies. Yogyakarta: KreasiWacana. Hlm. 83

${ }^{15}$ Yunita, Fera Intan. 2010. Fashion sebagaiManifestasiKapitalismeLanjutMenurut Pemikiran Michel

Foucault dan Jean Baudrillard. Jakarta:Universitas Indonesia. Hlm. 21
} 
melakukan peran yang diinginkannya. Perempuan justru terjebak pada mitos kecantikan yang selama ini menjeratnya, dimana peran yang diinginkannya tidak dapat dijalankannnya karena tidak memenuhi standarisasi penampilan dan kecantikan. Sebagaimana dikatakan oleh Wolf bahwa PBQ muncul bersamaan dengan mitos kecantikan itu sendiri, bersamaan dengan emansipasi perempuan dan menyebar bersamaan dengan kemampuan professional perempuan. ${ }^{16}$

Pertarungan wacana juga mulai terjadi antara kecantikan laki-laki dan kecantikan perempuan dalam hal karier. Jika sebelumnya perempuan menderita karena standarisasi kecantikan atau penampilan maka saat ini standarisasi itu juga telah merambah pada standarisasi penampilan laki-laki di dunia kerja. ${ }^{17}$ Penampilan laki-laki di dunia kerja menjadi begitu penting sama halnya dengan perempuan. Hal ini dilakukan oleh kapitalis untuk memperluas pasar produk kecantikannya. Wacana ini tidak begitu saja dilontarkan, tapi ada skenario di dalamnya dengan menjalin relasi kuasa. Permainan wacana ini dilakukan oleh para penguasa atau kapitalis untuk menciptakan produk kecantikan khusus bagi laki-laki. Wacana dominan maskulinitas yang dulu menjadi wacana dominan kini telah menjadi wacana yang terpinggirkan dan yang menjadi wacana dominan saat ini adalah wacana cowok metroseksual. Wacana memang terus berganti dan berkembang mengikuti alur jaringan penguasa untuk menetapkannya sebagai suatu kebenaran.

Kolom female banyak menggunakan kalimat yang menunjukkan proses mental. Kolom female menyadarkan pembaca tentang keterkaitan kecantikan dengan ketertarikan seseorang pada lawan jenisnya. Betapa pentingnya kecantikan fisik yang harus dimiliki untuk mendapat perhatian dari lawan jenisnya. Terutama untuk perempuan, penampilan fisik menjadi begitu penting, tolak ukur ketertarikan pria terhadap wanita adalah melalui wajah dan segala hal yang melekat pada tubuh perempuan. Artinya perempuan hanya bisa menarik perhatian laki-laki dengan cara visual atau melalui penglihatan. Wacana mengenai kecantikan selama ini banyak diperuntukkan bagi perempuan sehingga perempuan yang cantik dengan demikian merupakan sebuah simbol status dan simbol jiwa. ${ }^{18}$ Kolom female banyak menjelaskan tentang pentingnya kecantikan dan penampilan fisik bagi wanita terutama untuk memikat hati lelaki. Hal ini juga berpengaruh terhadap relasi antara suami dan istri dalam hubungan rumah tangga. Daya tarik fisik dijelaskan oleh kolom female sebagai indikator hubungan suami istri. Istri diharuskan memiliki penampilan fisik dan kecantikan yang lebih menarik daripada suami. Artinya penampilan suami tidak menjadi penting bagi istri, yang terpenting adalah postur tubuh dan penghasilannya yang tinggi. Penghasilan yang tinggi akan membuat perempuan untuk selalu tampil cantik dan menawan. Sedangkan pria membiayai segala kebutuhan kecantikannya agar merasa bangga ketika memiliki istri yang cantik dan merasa mampu untuk membiayai kecantikan istrinya. Artinya perempuan hanya dijadikan sebagai hiasan bagi suami ketika dia bersama istrinya pergi dalam acara-acara yang dihadiri oleh teman-teman suaminya. Kolom female masih menggunakan sudut pandang lakilaki untuk menyetujui pentingnya penampilan dan kecantikan bagi perempuan, terlebih dengan menampilkan pendapat pria terhadap perempuan yang hanya dijadikannya sebagai objek visual lelaki bahkan pelecehan seksual

\footnotetext{
${ }^{10}$ Idem. Hlm 63

${ }^{17}$ Idem. Hlm. 57

${ }^{18}$ Idem. Hlm. 147
} 


\section{Ideologi Dibalik Kolom Female}

Ideologi yang diusung oleh kolom female dalam media online Kompas.com berpengaruh pada penggunaan framing wartawan maupun editor dalam penulisan berita. Ada dua ideologi yang ada di balik berita kecantikan dalam female, diantaranya patriarkhi, kapitalisme, anti multikulturalisme dan kontra liberalisme.

\section{Kapitalisme}

Wacana kecantikan yang dikaitkan oleh kesuksesan dalam berkarier itu tidak luput dari adanya relasi kuasa untuk mendefinisikan, menciptakan dan melestarikan relasi kuasa. Foucault dalam Eriyanto mengatakan bahwa ciri utama wacana adalah kemampuannya untuk menjadi suatu himpunan wacana yang berfungsi membentuk dan melestarikan hubungan-hubungan kekuasaan dalam suatu masyarakat. ${ }^{19}$ Relasi kuasa yang terjalin antara kapitalis media dan kapitalis kecantikan dimanfaatkan oleh kapitalis yang lainnya untuk menghambat karier seseorang. Seperti halnya pada perempuan yang selama ini mendapatkan stereotipe negatif ketika perempuan cepat naik jabatan. Hal ini masih dipandang sebelah mata karena yang dilihat adalah fisiknya bukan karena prestasinya. Wacana ini juga diprodusir untuk memberikan efek pada golongan tertentu yakni mendapatkan keuntungan bagi kapitalis. Laki-laki dan perempuan dijebak dengan adanya PBQ, mereka bekerja menghabiskan banyak tenaga dan waktu kemudian mereka membelanjakannya untuk mendapatkan penampilan yang sempurna. Untuk mendapatkan penampilan itu pun mereka harus menghabiskan waktu, uang dan tenaga. Mereka terjebak pada budaya konsumtif karena pembelanjaan tidak untuk memenuhi kebutuhan tapi untuk mendapatkan citra dalam menarik perhatian orang lain.
Konsumsi menuntut diri kita mengaktualisasikan kapasitas dalam mendefinisikan citra atau identitas diri kita di bawah pengaruhnya, yang memungkinkan realitas kapitalis mengekang dan meniadakan kebebasan dalam konsumsi gaya hidup, karena sesungguhnya kebebasan itu adalah pilihan yang ditawarkan oleh kapitalisme multinasional. ${ }^{20}$

\section{Budaya Patriarkhi}

Sistem patriarkhi telah lama dikenal dan telah menjadi wacana tandingan bagi para feminis yang menyebarkan kebebasan perempuan. Patriarkhi ini dinilai berdampak buruk pada perempuan karena memandang perempuan dengan sebelah mata. Perempuan dipandang dari sudut pandang laki-laki, perempuan didominasi dalam segala aspek kehidupannya. Hal ini senada dengan apa yang dikatakan oleh Kamla Bhasin bahwa "Yang dihadapi oleh masyarakat sekarang adalah sebuah sistem yaitu sistem dominasi dan superioritas laki-laki, sistem kontrol terhadap perempuan dimana perempuan dikuasai. Melekat dalam sistem ini adalah ideologi yang menyatakan bahwa laki-laki lebih tinggi daripada perempuan, bahwa perempuan harus dikontrol oleh laki-laki dan bahwa perempuan adalah bagian dari milik laki-laki." ${ }^{21}$ Sama halnya dengan wacana kecantikan ini, perempuan telah dikontrol oleh laki-laki yang berada dalam kapitalis. Wacana ini memberikan dampak buruk pada perempuan, perempuan didisiplinkan, diatur bahkan dibuat tunduk dengan hukuman yang menyerang jiwa mereka.

Dalam hal ini kolom female masih melekatkan perempuan pada sektor domestik, sehingga menyalahkan perempuan yang gagal dalam melakukan perannya sebagai seorang ibu jika tidak mampu mensosialisasikan mitos kecantikan kepada anak-anaknya dengan tepat. Padahal tidak

\footnotetext{
${ }^{19}$ Idem. Hlm. 76

${ }^{20}$ Baudillard, Jean. 2004. MasyarakatKonsumsi. Yogyakarta: KreasiWacana.hlm. 78

${ }^{21}$ Kamla, Bhasin. 1996. Menggugat Patriarkhi Pengantar Tentang Persoalan Dominasi Terhadap Kaum Perempuan. Yogyakarta: Bentang Budaya. Hlm.14
} 
hanya ibu yang menjadi role model bagi seorang anak, melainkan seluruh anggota keluarga, lingkungan masyarakat dan bahkan media yang sering dilihatnya. Perempuan juga dinilia gagal sebagai istri jika tidak mampu menjaga kecantikannya, karena kecantikan perempuan merupakan simbol kekuasaan bagi seorang suami. Budaya patriarkhi masih menjadi framing wartawan kolom female dalam menyajikan suatu berita yang terjadi di sini adalah wacana patriarkhi yang masih belum menginginkan perempuan untuk tidak beranjak dari sektor domestik dan mendapatkan kesuksesan di sektor publik. Mitos kecantikan dibuat untuk menghalangi perempuan agar bisa menikmati hidupnya dengan terus menghamburkan banyak waktu, uang dan tenaga. Sebagaimana dinyatakan oleh Wolf "Dari sudut pandang masyarakat yang didominasi oleh lelaki, masyarakat terus mempertahankan energi perempuan yang berpendidikan dan punya waktu luang secara aman, bahkan mempergunakannya agar tidak ditujukan untuk melakukan pemberontakan. Dari sudut pandang perempuan, masyarakat memberikan makna untuk kehidupan mereka yang tidak produktif dari segi ekonomi." 22

\section{BALIK BERITA KOLOM FEMALE}

Kolom female dalam pemberitaannya mengaburkan beberapa poin penting. Diantaranya adalah pelabelan pada tubuh dengan ciri-ciri tertentu dan keterbatasan dalam pilihan yang diberikan oleh kolom female. Secara tidak langsung pemberian label dan keterbatasan pilihan ini tidak nampak. Namun kolom female menyajikannya sedemikian rupa agar pembaca dibuat untuk memiliki banyak pilihan dari berbagai pilihan yang ada dan dibuat untuk tidak sadar terhadap terhadap pelabelan dengan ciri-ciri tubuh tertentu. Adanya standarisasi kecantikan dan penampilan akan mendiskriminasi perempuan untuk tidak bisa melakukan peran yang diinginkannya. Perempuan justru terjebak pada mitos kecantikan yang selama ini menjeratnya, dimana peran yang diinginkannya tidak dapat dijalankannnya karena tidak memenuhi standarisasi penampilan dan kecantikan. Sebagaimana dinyatakan oleh Wolf bahwa semua profesi yang dirambah oleh perempuan diklasifikasikan kembali secara cepat, sejauh perempuan tetap menjadi pihak yang diperhatikan, sebagai penghias. Kecantikan menjadi sesuatu yang terkategorisasikan. ${ }^{23}$

Kolom female menggunakan kecantikan dengan menghubungkan pada peran perempuan merupakan suatu bentuk yang sebenarnya tidak ingin membebaskan perempuan untuk memilih perannya. Kecantikan menjadi suatu mitos baru untuk menghambat perempuan. Seolah-olah kolom female mendukung peran perempuan dalam hal karier namun sebenarnya perempuan diharuskan memilih pada pilihan-pilihan yang dibuat. Pertama, perempuan dibuat untuk memilih meninggalkan karier demi keutuhan rumah tangga. Kedua, perempuan tetap berkarier dan berumah tangga dengan lebih memprioritaskan rumah tangganya. Artinya kolom female masih memberatkan perempuan untuk total mengeskplorasi kemampuannya dalam berkarier. Perempuan masih selalu ditempatkan dalam peran domestiknya yang harus lebih diutamakan.

Tekanan-tekanan dari masalah rumah tangganya ini yang membuat perempuan untuk tidak dapat bergerak dalam ranah kariernya. Perempuan masih dibatasi dengan pilihan-pilihan yang ada dengan mengaburkan peran perempuan sebenarnya dalam kegiatan domestik dan publik. Wacana yang dibuat melalui iklan-iklan ini juga yang semakin menyerang

\footnotetext{
${ }^{22}$ Ibid. Hlm 176
}

${ }^{23}$ Ibid. Hlm. 56 
mental perempuan tentang kecantikan yang akan menentukan keberhasilan karier dan keharmonisan rumah tangganya. Wacana ini disusun melalui framing tertentu yang memang menginginkan perempuan untuk mengalihkan perhatiannya dari hal yang subtansi pada hal-hal palsu yang dibuat oleh kapitalis.

Seharusnya perempuan lebih difokuskan pada perannya dalam domestik dan karier. Namun dengan iklan-iklan itu justru perempuan dialihkan perhatiannya pada mitos kecantikan yang dinilai dapat menjadi solusi bagi masalah peran yang sedang dihadapi. Padahal yang menjadi solusi adalah bagaimana perempuan mengatur waktu, tenaga dan pikiran serta membangun komunikasi dan relasi yang baik antara dirinya dengan pasangannya agar pasangan dapat mendukung peran perempuan dalam kedua ranah tersebut. Namun justru perempuan makin banyak menghabiskan energi dan waktu

\section{"Mitos kecantikan ini hanyalah kebohongan yang dibuat oleh kapitalis yang seolah membebaskan perempuan tapi justru makin mengekang perempuan." Yelly Elanda}

untuk mengejar-ngejar kecantikan ideal. Mitos kecantikan ini hanyalah kebohongan yang dibuat oleh kapitalis yang seolah membebaskan perempuan tapi justru makin mengekang perempuan. Sebagaimana dinyatakan oleh Synnott bahwa "Kecantikan dalam pandangan ini bukanlah kebaikan, melainkan kejahatan; bukan lagi investasi, melainkan penyia-nyiaan; bukan lagi kebenaran melainkan kebohongan; seperti selalu dikatakan oleh para satir; bukan hikmat, melainkan kebodohan; bukan kesenangan, melainkan politis; bukan kehidupan melainkan sesuatu yang membahayakan hidup dan kesehatan; bukan kebebasan, melainkan sebuah jebakan; bukan solusi melainkan persoalan sosial yang utama." 24

\section{KESIMPULAN}

Kolom female merupakan salah satu bagian dari media online Kompas.com yang diharapkan dapat memberikan ruang bagi perempuan untuk mendapatkan berbagai informasi, motivasi serta inspirasi agar perempuan diakui keberadaannya sebagai subjek. Namun ternyata kolom female tidak hanya diperuntukkan bagi perempuan, melainkan juga mengenalkan cowok metroseksual dengan menghadirkan laki-laki yang diidolakan oleh perempuan, lelaki yang melakukan perawatan kecantikan. Sebagian besar tulisan dari kolom female merupakan turunan dari iklan produk kecantikan dan klinik kecantikan. Jadi kolom female dibuat bukan untuk menampung kepentingan perempuan, tapi justru untuk mengakomodir kepentingan kapitalis yang termaktub dalam berita-berita yang disajikan.

Mitos kecantikan telah menjebak perempuan dan laki-laki dengan persyaratan penampilan menarik dalam karier. Perempuan mendapatkan streotipe jika kariernya cemerlang, bukan karena kemampuannya melainkan karena penampilannya. Dalam hal percintaan pun, perempuan dituntut untuk tampil cantik di depan pria agar dapat menarik perhatian sehingga memberikan suatu kebanggaan. Sedangkan laki-laki dituntut untuk memiliki banyak uang agar dapat mendapatkan wanita yang cantik karena kecantikan wanita merupakan simbol kekuasaan laki-laki. Wacana ini seolah membuat laki-laki dan perempuan bekerja untuk kepentingan kapitalis dengan menghabiskan banyak waktu dan tenaga, hanya untuk memenuhi kebutuhan penampilannya yang juga dibuat oleh kapitalis.

Kolom female seharusnya seimbang dalam melakukan pemberitaan, terlebih untuk menyampaikan suatu pesan moral yakni menghormati perbedaan dalam nilai keberagaman.

${ }^{24}$ Ibid. Hlm. 67 
Namun ternyata masih mendiskriminasi perempuan melalui mitos kecantikan yang diidentikkan dengan ciri tubuh tertentu untuk menunjukkan identitas. Kolom female memberikan stereotipe seksi, eksotis, dan unik jika sosok perempuan tersebut tidak sesuai dengan iron maiden yang ditampilkan. Iron maiden dalam kolom female digambarkan sebagai sosok dengan kecantikan yang natural. Kecantikan natural yang dimaksud bukan tampil apa adanya namun dengan menggunakan produk kecantikan dan melakukan terapi di klinik kecantikan bahkan dengan melakukan operasi plastik agar nampak cantik natural. Kolom female menggunakan politik pencitraan untuk menempatkan perempuan sebagai objek konsumtif dengan memberikan citra tubuh disiplin dan tubuh plastik pada perempuan untuk mendapatkan kecantikan natural.

Kolom female seolah memberikan keberagaman wacana kecantikan dengan berbagai tawaran model dari beberapa negara. Namun pilihan wacana kecantikan itu terbatas, pilihan itu dibuat oleh kapitalis untuk mendapatkan keuntungan dengan membeli produk kecantikan dan segala ritualnya. Pilihan itu masih terjebak pada subjektivitas dalam memaknai kecantikan. Kolom female juga seolah membebaskan perempuan untuk memilih dunia publik atau dunia domestik namun secara keseluruhan masih berkutat pada sektor domestik karena kehidupan perempuan pada karier selalu diberatkan pada perannya dalam rumah tangga. Pola asuh anak dibebankan hanya pada perempuan. Kolom female juga memposisikan perempuan menjadi simbol bagi pasangannya. Wacana ini berusaha mengandangkan perempuan kembali pada sektor domestik dengan menghabiskan banyak waktu, tenaga dan uang untuk kecantikan. Kolom female masih menguatkan budaya patriarkhi dalam mengkonstruksi peran perempuan.

Media nasional yang oplahnya terbesar ini seharusnya memberikan wacana kebaikan jiwa tapi justru menggunakan wacana kecantikan fisik untuk mengukur kebaikan perempuan. Kebaikan hati dan jiwa sosial hanya diukur sebatas materi. Kebaikan hati justru menjadi ajang untuk memperlihatkan status sosialnya. Setelah dianalisis lebih cermat, perempuan masih ditempatkan sebagai objek dan masih lekat dengan kegiatan domestik. Wacana dalam kolom female yang diharapkan dapat membebaskan perempuan masih tidak bisa beranjak dari budaya patriarkhi karena dikooptasi oleh kepentingan kapitalis.

\section{DAFTAR PUSTAKA}

Barker, Chris. Cultural Studies. Yogyakarta: Kreasi Wacana

Baudillard, Jean. 2004. Masyarakat Konsumsi. Yogyakarta: KreasiWacana

Darma,Aliah Yoce.2009. Analisis Wacana Kritis. Bandung: YramaWidya

Erianjoni. 2009. Konstruksi Media terhadap Pencitraan Wanita: Studi Semiotik Pencitraan

Eriyanto. 2005. Analisi Framing. Yogyakarta: LkiS Fairclough, Norman. 1995. Critical Discourse Analysis: The Critical Study of Identitas Perempuan Kelas Menengah di Perkotaan. Jurnal Komunitas. Volume 5

Kamla, Bhasin. 1996. Menggugat Patriarkhi PengantarT entang Persoalan Dominasi Kecantikan di Majalah Femina Edisi Mei 2011. Jurnal Komunikasi Volume 9 Nomor 2. 67-73

Language. Singapore: Longman Singapore Publishers (Pte) Ltd

Marlianti, Nelly dan Suryani, Ade. 2012. Representasi Tubuh Perempuan dalam Rubrik Michel Foucault dan Jean Baudrillard. Jakarta: Universitas Indonesia Nomor 1. 1-24

Padang. Jurnal Demokerasi Volume VIII No. 2. 107-129 Siregar, Aprilandini Yuanita. 2011. Pencitraan Perempuan di Majalah: Konstruksi

Synnott, Anthony. 2007. Tubuh Sosial. Yogyakarta: Jalasutra Terhadap Kaum Perempuan. Yogyakarta: Bentang Budaya

Wanita Minangkabau dalam Rubrik Kontak Jodoh di Media Lokal Harian Haluan 
Wolf, Naomi. 2004. Mitos Kecantikan.

Yogyakarta: Niagara

Yunita, Fera Intan. 2010. Fashion sebagai Manifestasi Kapitalisme Lanjut Menurut Pemikiran

\section{Sumber Internet:}

http://inside.kompas.com/about-us. diakses tanggal 13 Oktober 2015 jam 19.25 